The University of Maine

\title{
DigitalCommons@UMaine
}

Marine Sciences Faculty Scholarship

School of Marine Sciences

3-18-2011

\section{Freshening of the Alaska Coastal Current Recorded By Coralline Algal Ba/Ca Ratios}

P. Chan

J. Halfar

B. Williams

S. Hetzinger

Robert Steneck

University of Maine - Main, steneck@maine.edu

See next page for additional authors

Follow this and additional works at: https://digitalcommons.library.umaine.edu/sms_facpub

\section{Repository Citation}

Chan, P.; Halfar, J.; Williams, B.; Hetzinger, S.; Steneck, Robert; Zack, T.; and Jacob, D. E., "Freshening of the Alaska Coastal Current Recorded By Coralline Algal Ba/Ca Ratios" (2011). Marine Sciences Faculty Scholarship. 51.

https://digitalcommons.library.umaine.edu/sms_facpub/51 
Authors

P. Chan, J. Halfar, B. Williams, S. Hetzinger, Robert Steneck, T. Zack, and D. E. Jacob 


\title{
Freshening of the Alaska Coastal Current recorded by coralline algal $\mathrm{Ba} / \mathrm{Ca}$ ratios
}

\author{
Phoebe Chan, ${ }^{1}$ Jochen Halfar, ${ }^{1}$ Branwen Williams, ${ }^{1}$ Steffen Hetzinger, ${ }^{1,2}$ Robert Steneck, ${ }^{3}$ \\ Thomas Zack, ${ }^{4}$ and Dorrit E. Jacob ${ }^{4}$ \\ Received 21 September 2010; revised 22 November 2010; accepted 22 December 2010; published 18 March 2011.
}

[1] Arctic Ocean freshening can exert a controlling influence on global climate, triggering strong feedbacks on ocean-atmospheric processes and affecting the global cycling of the world's oceans. Glacier-fed ocean currents such as the Alaska Coastal Current are important sources of freshwater for the Bering Sea shelf, and may also influence the Arctic Ocean freshwater budget. Instrumental data indicate a multiyear freshening episode of the Alaska Coastal Current in the early 21st century. It is uncertain whether this freshening is part of natural multidecadal climate variability or a unique feature of anthropogenically induced warming. In order to answer this, a better understanding of past variations in the Alaska Coastal Current is needed. However, continuous long-term high-resolution observations of the Alaska Coastal Current have only been available for the last 2 decades. In this study, specimens of the long-lived crustose coralline alga Clathromorphum nereostratum were collected within the pathway of the Alaska Coastal Current and utilized as archives of past temperature and salinity. Results indicate that coralline algal $\mathrm{Mg} / \mathrm{Ca}$ ratios provide a 60 year record of sea surface temperatures and track changes of the Pacific Decadal Oscillation, a pattern of decadal-to-multidecadal ocean-atmosphere climate variability centered over the North Pacific. Algal $\mathrm{Ba} / \mathrm{Ca}$ ratios (used as indicators of coastal freshwater runoff) are inversely correlated to instrumentally measured Alaska Coastal Current salinity and record the period of freshening from 2001 to 2006. Similar multiyear freshening events are not evident in the earlier portion of the 60 year $\mathrm{Ba} / \mathrm{Ca}$ record. This suggests that the 21 st century freshening of the Alaska Coastal Current is a unique feature related to increasing glacial melt and precipitation on mainland Alaska.

Citation: Chan, P., J. Halfar, B. Williams, S. Hetzinger, R. Steneck, T. Zack, and D. E. Jacob (2011), Freshening of the Alaska Coastal Current recorded by coralline algal Ba/Ca ratios, J. Geophys. Res., 116, G01032, doi:10.1029/2010JG001548.

\section{Introduction}

[2] Freshening of the Arctic Ocean can have considerable impacts on ocean stratification and ventilation [Woodgate et al., 2005], affecting the Arctic sea ice budget [Paquette and Bourke, 1981; Shimada et al., 2006; Mizobata et al., 2010]. Furthermore, Arctic freshening can disrupt the flow of largescale circulation features such the Atlantic thermohaline circulation [Rahmstorf, 1995; Peterson et al., 2002; Woodgate et al., 2006; Kuhlbrodt et al., 2009]. Recent studies indicate a significant warming and freshening of the Bering Strait throughflow into the Arctic Ocean [Woodgate and Aagaard, 2005; Royer and Grosch, 2006; Woodgate et al., 2006; Ladd

\footnotetext{
${ }^{1}$ Chemical and Physical Sciences Department, University of Toronto, Mississauga, Ontario, Canada.

${ }^{2}$ Now at Leibniz Institute of Marine Sciences at University of Kiel (IFM-GEOMAR), Kiel, Germany.

${ }^{3}$ Darling Marine Center, University of Maine, Walpole, Maine, USA.

${ }^{4}$ Earth System Science Research Centre, Johannes GutenbergUniversität, Mainz, Germany.

Copyright 2011 by the American Geophysical Union. 0148-0227/11/2010JG001548
}

and Stabeno, 2009; Mizobata et al., 2010; Woodgate et al., 2010]. The Bering Strait throughflow accounts for approximately one third of the Arctic Ocean freshwater budget, a quarter of which is determined by freshwater influx from the Alaska Coastal Current, which originates in the Gulf of Alaska and later combines with freshwater from the rivers of western Alaska [Woodgate and Aagaard, 2005; Aagaard et al., 2006; Woodgate et al., 2006]. The Alaska Coastal Current is a narrow coastal jet fed by terrestrial freshwater runoff from British Columbia and mainland Alaska [Weingartner et al., 2005]. It flows westward along the southern coastline of Alaska, through the narrow Unimak Pass and into the Bering Sea (Figure 1a) [Schumacher et al., 1982; Stabeno et al., 2002]. A recent increase in glacial melt in southeast Alaska suggests a growing freshwater contribution of the Alaska Coastal Current to Bering Strait throughflow [Arendt et al., 2002; Royer and Grosch, 2006; Arendt et al., 2009]. While a 20th century runoff record from Gulf of Alaska rivers permits retrospective examination of the Alaska Coastal Current, coastal observations of salinity appear to be better predictors of ACC freshwater variability [Weingartner et al., 2005]. However, long-term high-resolution nearshore oceanographic 


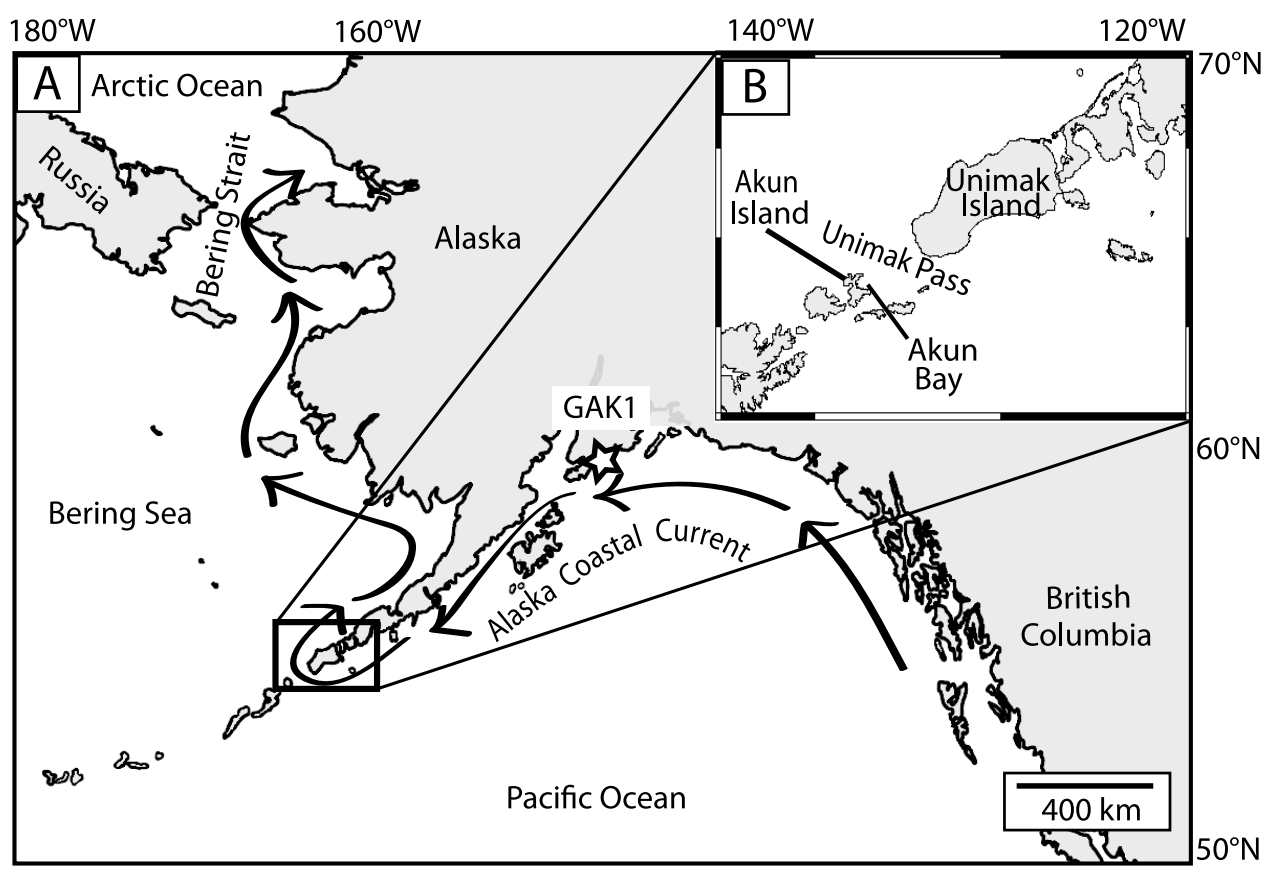

Figure 1. (a) Map of North Pacific/Bering Sea region and Aleutian archipelago. Arrows depict pathway of Alaska Coastal Current based on data from Schumacher et al. [1982]. Star represents location of GAK 1 oceanographic station. (b) Sample collection site in Akun Bay, west of Unimak Pass.

observations of Alaska Coastal Current freshwater variability are absent prior to the 1970 s.

[3] In this study, we use the nearshore crustose coralline algae Clathromorphum nereostratum as a long-term archive for past temperature and salinity variations in the Alaska Coastal Current. High-Mg calcite secreting photosynthetic coralline algae are well-suited for midlatitude to high-latitude century-long oceanographic reconstructions on high-resolution timescales [Halfar et al., 2007; Kamenos et al., 2008; Hetzinger et al., 2009]. Stable oxygen isotopes and $\mathrm{Mg} / \mathrm{Ca}$ ratios from different species of Clathromorphum track in situ sea surface temperatures as well as large-scale climate patterns such as the El Niño Southern Oscillation, North Atlantic Oscillation and Pacific Decadal Oscillation [Halfar et al., 2007; Gamboa et al., 2010].

[4] In contrast, $\mathrm{Ba} / \mathrm{Ca}$ ratios in Clathromorphum display weak correlations with temperature [Hetzinger et al., 2011], but respond to variability in surface ocean Ba content. Upper ocean Ba concentrations are influenced by upwelling of cold Ba-rich deep waters, or by coastal influx of suspended sediments [Alibert et al., 2003]. In open ocean settings, Ba is often depleted in surface waters and enriched in deep waters due to the uptake of $\mathrm{Ba}$ as barite $\left(\mathrm{Ba} \mathrm{SO}_{4}\right)$, associated with the formation of biological particulate matter [Chan et al., 1977; Dehairs et al., 1980; Collier and Edmond, 1984; Dehairs et al., 1987; Bishop, 1988; Lea and Boyle, 1989; Lea et al., 1989; Lea and Boyle, 1991; Falkner et al., 1993]. However, corals growing close to shore experience higher levels of $\mathrm{Ba}$ compared to those in the open ocean [Shen and Boyle, 1988]. $\mathrm{Ba}$ is abundant in estuarine environments due to high terrestrial freshwater and sediment influx into coastal waters [Coffey et al., 1997]. Ba previously absorbed by riverine clay minerals is released into the ocean upon encountering more alkaline elements (i.e., $\mathrm{Ca}, \mathrm{Mg}$, and $\mathrm{Sr}$ ) present in the sea- water [Hanor and Chan, 1977; Li and Chan, 1979; Shen and Boyle, 1988; Guay and Falkner, 1998; Falkner et al., 1994; Sinclair and McCulloch, 2004]. Thereafter, Ba commonly behaves as a conservative dissolved tracer, and is incorporated into the carbonate skeleton of calcifying organisms in proportion to ambient seawater concentrations [Lea et al., 1989]. Skeletal $\mathrm{Ba} / \mathrm{Ca}$ ratios have proven to be a valuable proxy for seawater $\mathrm{Ba} / \mathrm{Ca}$, providing information on coastal sediment transport, freshwater discharge, salinity, as well as nutrient and alkalinity distributions [Lea and Boyle, 1989, 1991; Sinclair et al., 1998; McCulloch et al., 2003; Sinclair and McCulloch, 2004; Fleitmann et al., 2007; Grove et al., 2010]. However, these $\mathrm{Ba} / \mathrm{Ca}$-based proxy studies have typically been conducted in tropical, low-latitude regions. In the North Pacific where historical records are sparse, a proxy for long-term changes in freshwater variability of the Alaska Coastal Current would be highly valuable. Here we employ coralline algal $\mathrm{Ba} / \mathrm{Ca}$ and $\mathrm{Mg} / \mathrm{Ca}$ ratios to reconstruct temperature and salinity variability of the Alaska Coastal Current in order to demonstrate that a recent freshening episode of the Alaska Coastal Current is unprecedented during the last 60 years.

\section{Methods}

[5] In June 2008, living specimens of the coralline alga Clathromorphum nereostratum were collected at $10 \mathrm{~m}$ water depth using SCUBA from Akun Bay $\left(54.2^{\circ} \mathrm{N}, 165.5^{\circ} \mathrm{W}\right)$ on the western shore of Unimak Pass, the main conduit for flow of the Alaska Coastal Current from the North Pacific into the Bering Sea (Figure 1b) [Stabeno et al., 2002]. Samples were sectioned vertically and polished to $1 \mu \mathrm{m}$. Highresolution digital photomosaics of the polished specimens were scanned using an automated sampling stage-imaging 


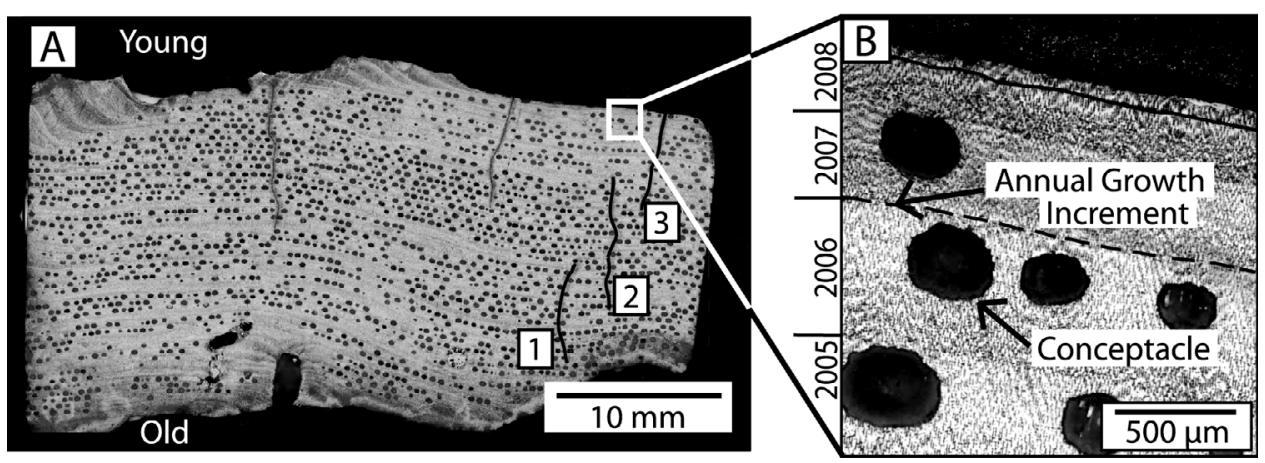

Figure 2. (a) Overview image of polished $C$. nereostratum thick section with overlapping laser transects (lines 1, 2, and 3). Element ratios obtained from overlapping sections were averaged. (b) Magnified view of alga depicting annual growth increments and conceptacle cavities.

system equipped with Geo.TS (Olympus Soft Imaging Systems) software (for details, see Hetzinger et al. [2009]). The resulting photomosaics enabled the identification of annual growth increments which are identified by the occurrence of rows of annually forming conceptacles (cavities containing reproductive structures) (Figures $2 \mathrm{a}$ and $2 \mathrm{~b}$ ). Laser-line transects were digitized along the growth axis of each sample using Geo.TS (Figures 2a and 3), carefully avoiding conceptacle cavities and areas of discontinuous growth. The resulting $\mathrm{x}, \mathrm{y}$ coordinates were used for positioning line transects for Laser Ablation Inductively Coupled Plasma Mass Spectrometer (LA-ICP-MS) analysis.

[6] LA-ICP-MS analysis of $\mathrm{Mg} / \mathrm{Ca}$ and $\mathrm{Ba} / \mathrm{Ca}$ elemental ratios were conducted at the Earth System Science Research Centre at the University of Mainz Germany, using an Agilent 7500 ce Quadrupole ICP-MS attached to a New Wave Research UP-213 laser ablation system equipped with a large format cell. Laser measurements were performed using laser energy densities of $6 \mathrm{~J} / \mathrm{cm}^{2}$, and helium as a carrier gas. Transect lengths were limited to $6000 \mu \mathrm{m}$ in order to minimize the effect of ICP-MS drift and were analyzed at a scan speed of $10 \mu \mathrm{m} /$ second, with a $65 \mu \mathrm{m}$ spot size and $10 \mathrm{~Hz}$ pulse rate. NIST SRM 610 (U.S. National Institute of Standard and Technology Standard Reference Material) glass reference material was used as an external standard. Data for NIST SRM 610 were extracted from the GeoReM database available from (http://georem.mpch-mainz.gwdg.de/sample query_pref.asp). Detection limits were: $\mathrm{Mg}=0.02 \mathrm{ppm}, \mathrm{Ca}=$ $5.47 \mathrm{ppm}, \mathrm{Ba}=0.01 \mathrm{ppm}$. Additional details on the analytical setup used can be found in the works of Jacob [2006] and Hetzinger et al. [2011].

[7] Subannually resolved age models were constructed using annual variations in algal $\mathrm{Mg} / \mathrm{Ca}$. Calendar years were assigned to annual growth increments starting from 2008 (year of collection) and extending back in time. The $\mathrm{Mg} / \mathrm{Ca}$ cycles were then graphically superimposed on a photomosaic of the sample surface depicting the laser transects where maxima in $\mathrm{Mg} / \mathrm{Ca}$ were aligned with the center of each growth increment, and minima with growth increment transitions (Figure 3). Using the compiled information from the $\mathrm{Mg} / \mathrm{Ca}$ cycles and photomosaics, subannual markers were assigned to the maxima (representing the warmest month of the year) and minima (representing the coldest month of the year) of each annual $\mathrm{Mg} / \mathrm{Ca}$ cycle. Based on monthly sea surface temperature averages from bias-corrected satellite measurements obtained from Reynolds Optimum Interpolation sea surface temperature analysis (1982-2008), the month exhibiting the warmest (coldest) temperature at Akun Bay was August (March) [Reynolds et al., 2002]. Markers were assigned beginning at the first minimum (i.e., March 2007), followed by the first maximum (i.e., August 2006), and continuing back in time. The algal time series was linearly

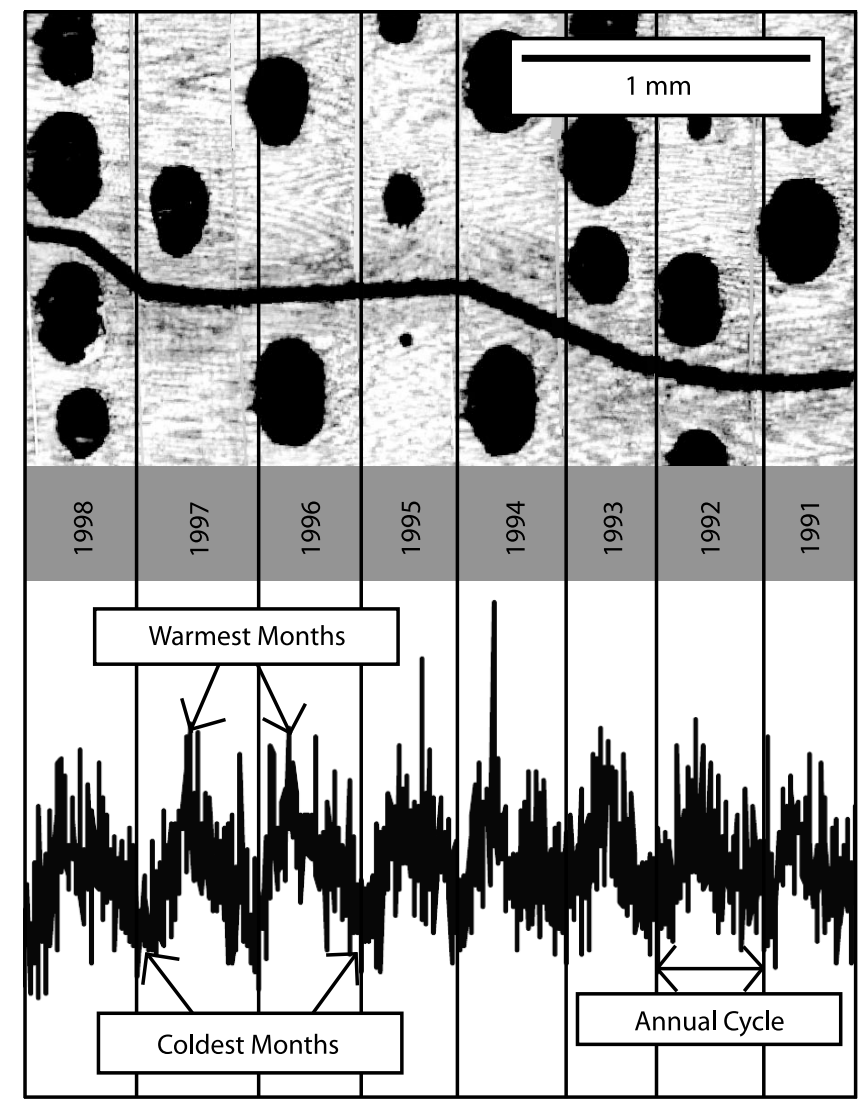

Figure 3. Algal $\mathrm{Mg} / \mathrm{Ca}$ cycles obtained from LA-ICP-MS superimposed on photomosaic of sample cross section with laser transect. $\mathrm{Mg} / \mathrm{Ca}$ measurements display distinct seasonal cycles. Areas with high (low) $\mathrm{Mg} / \mathrm{Ca}$ ratios are interpreted to be summer (winter) periods of algal growth, with one full cycle representing 1 calendar year. Calendar years were assigned by counting annual growth increments. 


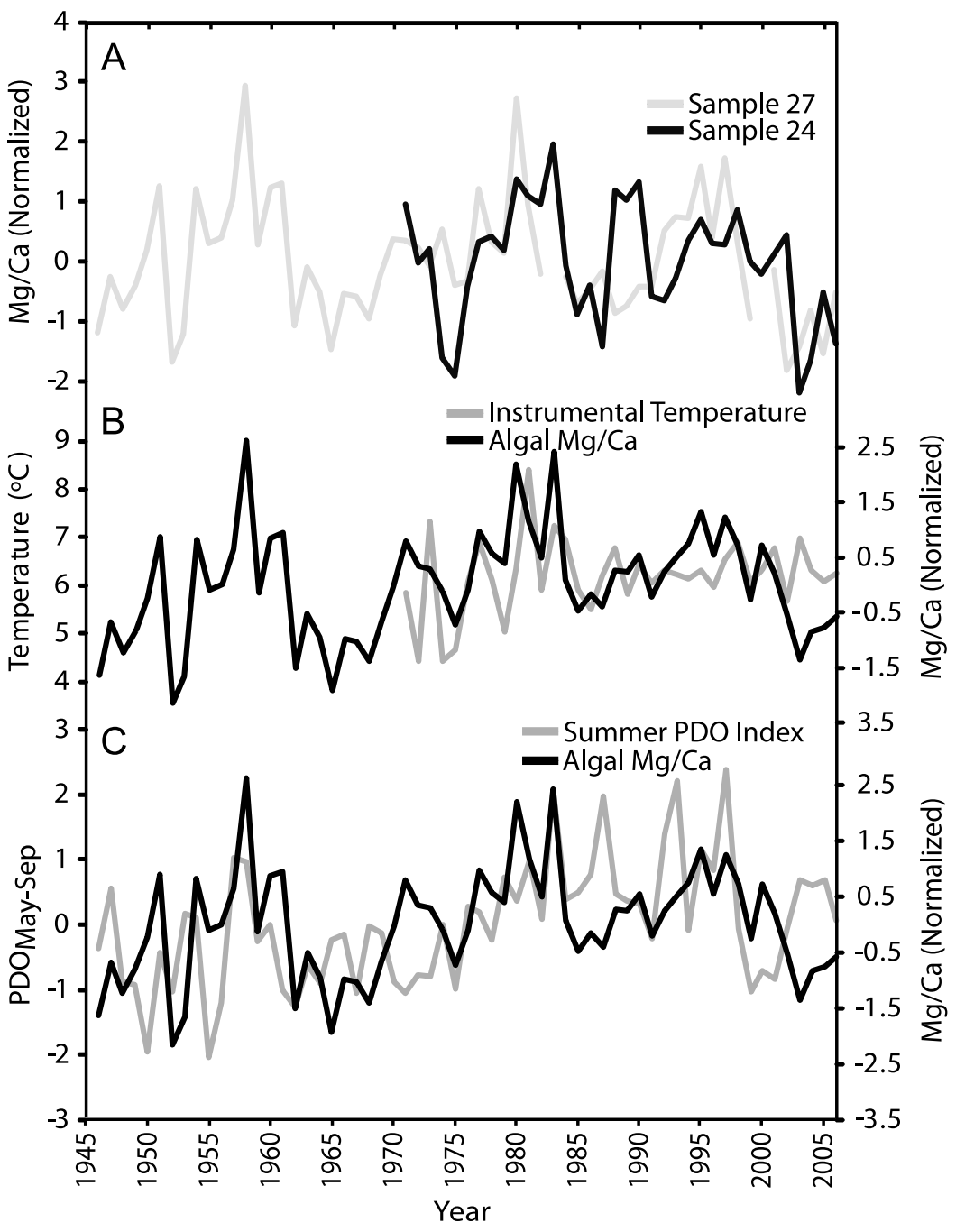

Figure 4. (a) C. nereostratum $\mathrm{Mg} / \mathrm{Ca}$ time series from samples 24 and 27. Overlapping regions in laser transects were averaged to create the final $\mathrm{Mg} / \mathrm{Ca}$ time series. (b) Annual algal $\mathrm{Mg} / \mathrm{Ca}$ time series (averaged) compared to annual mean instrumental temperature from oceanographic station GAK $1(1971-2006 ; \mathrm{n}=35$, $r=0.32, \mathrm{p}=0.06$ ). (c) Annual algal $\mathrm{Mg} / \mathrm{Ca}$ correlated to Pacific Decadal Oscillation (May-September) index $(\mathrm{n}=60, r=0.41, \mathrm{p}=0.001)$.

interpolated between these anchor points using AnalySeries software [Paillard et al., 1996] to obtain a proxy time series with monthly resolution. Since algal $\mathrm{Ba} / \mathrm{Ca}$ ratios do not exhibit annual cyclicity, the anchor points derived from the $\mathrm{Mg} / \mathrm{Ca}$ age model were adapted to the $\mathrm{Ba} / \mathrm{Ca}$ data. In addition, given that coralline growth rates vary throughout the year (e.g., highest rates in summer, lowest in winter, insignificant or no growth between January and April) the 12 equidistant data points were assigned to growing season months according to a growth model established by Halfar et al. [2008].

[8] The final algal record was constructed from the average of two samples: sample 24 from 1971 to 2006; and sample 27 from 1946 to 2006 (Figure 4a). The resulting algal Mg/Ca and $\mathrm{Ba} / \mathrm{Ca}$ time series were correlated to instrumental temperature and salinity observations. Since long-term, highresolution in situ oceanographic data are nonexistent from Unimak Pass, sea surface temperature and salinity observations from oceanographic station GAK 1 (located within the flow of the narrow Alaska Coastal Current at the mouth of Resurrection Bay, Alaska; $59.8^{\circ} \mathrm{N}, 149.5^{\circ} \mathrm{W}$; Figure 1a), were used for correlations with algal elemental ratios (GAK 1 data are available from http://www.ims.uaf.edu/gak1/). GAK 1 observations from the early 1970s and 1980s are sparse and irregular [Janout et al., 2010]. However, since 1991 more frequent quasi-monthly measurements of temperature and salinity have been made available using conductivity, temperature, depth recorder casts with accuracies of $\pm 0.1^{\circ} \mathrm{C}$ and $\pm 0.2 \mathrm{psu}$ for temperature and salinity, respectively [Royer and Grosch, 2006].

\section{Results and Discussion}

\section{1. $\mathrm{Mg} / \mathrm{Ca}-$ Temperature Relationship}

[9] Linear regression analysis reveals that annually averaged algal $\mathrm{Mg} / \mathrm{Ca}$ ratios are weakly correlated to annual mean sea surface temperatures at GAK $1,1400 \mathrm{~km}$ to the east of the coralline algal collection site at Unimak Pass (Figure 4b; 


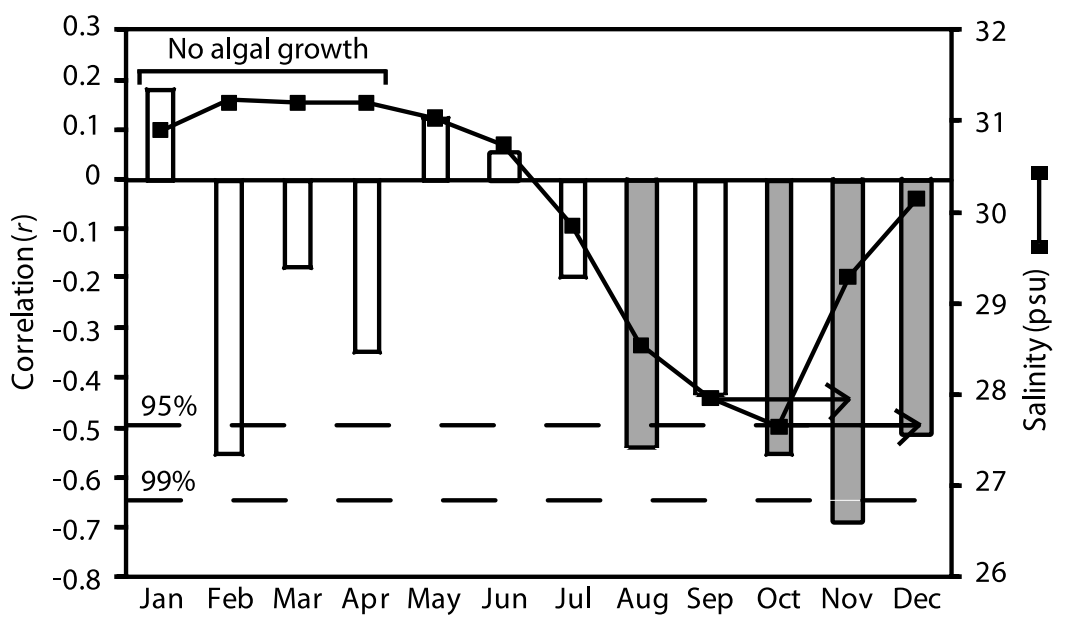

Figure 5. Correlation of annually averaged $\mathrm{Ba} / \mathrm{Ca}$ values of $C$. nereostratum with monthly GAK 1 salinity (1991-2006). Black line indicates monthly salinity average at GAK 1 for the same time period. Arrows depict recording lag of algae due to transport time between GAK 1 and Unimak Pass. Note that algal growth is insignificant from January through April.

$\mathrm{n}=35, r=0.32, \mathrm{p}=0.06)$. In the absence of longer nearby multidecadal instrumental temperature time series, the algal $\mathrm{Mg} / \mathrm{Ca}$-temperature relationship was also compared with the large-scale pattern of the summer Pacific Decadal Oscillation (May-September) (Figure 4c; $\mathrm{n}=60, r=0.41, \mathrm{p}=$ 0.001). Algal $\mathrm{Mg} / \mathrm{Ca}$ ratios closely track the decadal-tomultidecadal variability of the Pacific Decadal Oscillation, the dominant pattern influencing North Pacific climate on 20-30 year periodicities [Mantua et al., 1997]. While the expression of the Pacific Decadal Oscillation is strongest in the Gulf of Alaska, the Pacific Decadal Oscillation signal is likely advected from the Gulf of Alaska to Unimak Pass via the Alaska Coastal Current [Weingartner et al., 2005]. This is consistent with a 117 yearlong $C$. nereostratum oxygen isotope record from the western Aleutian Islands located within the pathway of the Alaskan Stream, which also exhibited positive Pacific Decadal Oscillation correlations [Halfar et al., 2007]. Here, algal Mg/Ca ratios closely track sea surface temperature patterns, although correlations with both instrumental temperatures and the Pacific Decadal Oscillation are significantly diminished after 2002. This divergence could reflect a salinity effect on the incorporation of $\mathrm{Mg}$ into the algal skeleton caused by strong freshening of the Alaska Coastal Current beginning in 2001. In fact, recent studies of high-Mg calcite in echinoderm skeletons and foraminiferal tests field-collected or cultured in different salinities have demonstrated a clear negative effect on $\mathrm{Mg} / \mathrm{Ca}$ ratios [Ferguson et al., 2008; Kisakürek et al., 2008; Borremans et al., 2009].

\subsection{Timing of Alaska Coastal Current Freshwater Signal at Unimak Pass}

[10] Annually averaged $\mathrm{Ba} / \mathrm{Ca}$ ratios were compared to monthly instrumental GAK 1 salinities for the period of quasi-monthly instrumental observations (1991-2006) in order to determine the seasonal timing of the Alaska Coastal Current freshening at Unimak Pass. The annual cycle of sea surface salinity observed at GAK 1 is characterized by high values spanning from winter to spring (December-July), declining to the lowest values in the fall (August-November) associated with the period of maximum discharge due to fall storm activity [Royer, 1982] and enhanced glacial melt (Figure 5, black line). Satellite-tracked drifter measurements have revealed an average transport time of $\sim 2.5$ months from the head of the Gulf of Alaska (approximate location of GAK 1) to Unimak Pass, located $1400 \mathrm{~km}$ to the west [Stabeno et al., 2002]. Therefore, the significant negative correlations between annual $\mathrm{Ba} / \mathrm{Ca}$ and monthly $\mathrm{GAK} 1$ salinity from mid to late fall demonstrates the propagation of the September-November freshening signal at GAK 1 to the algal collection site, resulting in an increase in algal $\mathrm{Ba} / \mathrm{Ca}$ values from October-December (Figure 5, gray bars). Significant $\mathrm{Ba} / \mathrm{Ca}-\mathrm{GAK} 1$ salinity correlations during August are attributed to late spring snowmelt [Royer, 2005] in mainland Alaska. Correlations in late winter and early spring were not included in the analyses, as the algae do not to exhibit significant growth during these months [Halfar et al., 2008]. In the following we focus on comparing the fall maximum discharge (September-November) recorded by GAK 1 salinities with the lagged OctoberDecember algal $\mathrm{Ba} / \mathrm{Ca}$ ratios.

\section{3. $\mathrm{Ba} / \mathrm{Ca}-$ Freshwater Relationship}

[11] An algal $\mathrm{Ba} / \mathrm{Ca}$ time series was constructed from the average of samples 24 and 27 (Figure 6a). Algal $\mathrm{Ba} / \mathrm{Ca}$ (October-December) ratios are significantly correlated with GAK 1 (September-November) salinities $(0-20 \mathrm{~m})$ from 1971 to 2006 (Figure 6b; $\mathrm{n}=35, r=-0.65, \mathrm{p}<0.0001$ ). Furthermore, a brief freshening event recorded by GAK 1 in 1990 is recorded by both algal samples, with sample 27 showing a strong increase in $\mathrm{Ba} / \mathrm{Ca}$. This demonstrates that algal $\mathrm{Ba} / \mathrm{Ca}$ ratios at Unimak Pass provide a continuous and reliable record of the Alaska Coastal Current freshwater signature. Algal $\mathrm{Ba} / \mathrm{Ca}$ ratios can therefore be used to reconstruct Alaska Coastal Current freshwater transport prior to 1970 when instrumental observations are nonexistent.

[12] A recent freshening episode of the Alaska Coastal Current is represented by a decrease in GAK 1 salinities and an increase in algal $\mathrm{Ba} / \mathrm{Ca}$ from 2001 to 2006 (Figure 6b, gray box). The multiyear episode of 21 st century freshening 


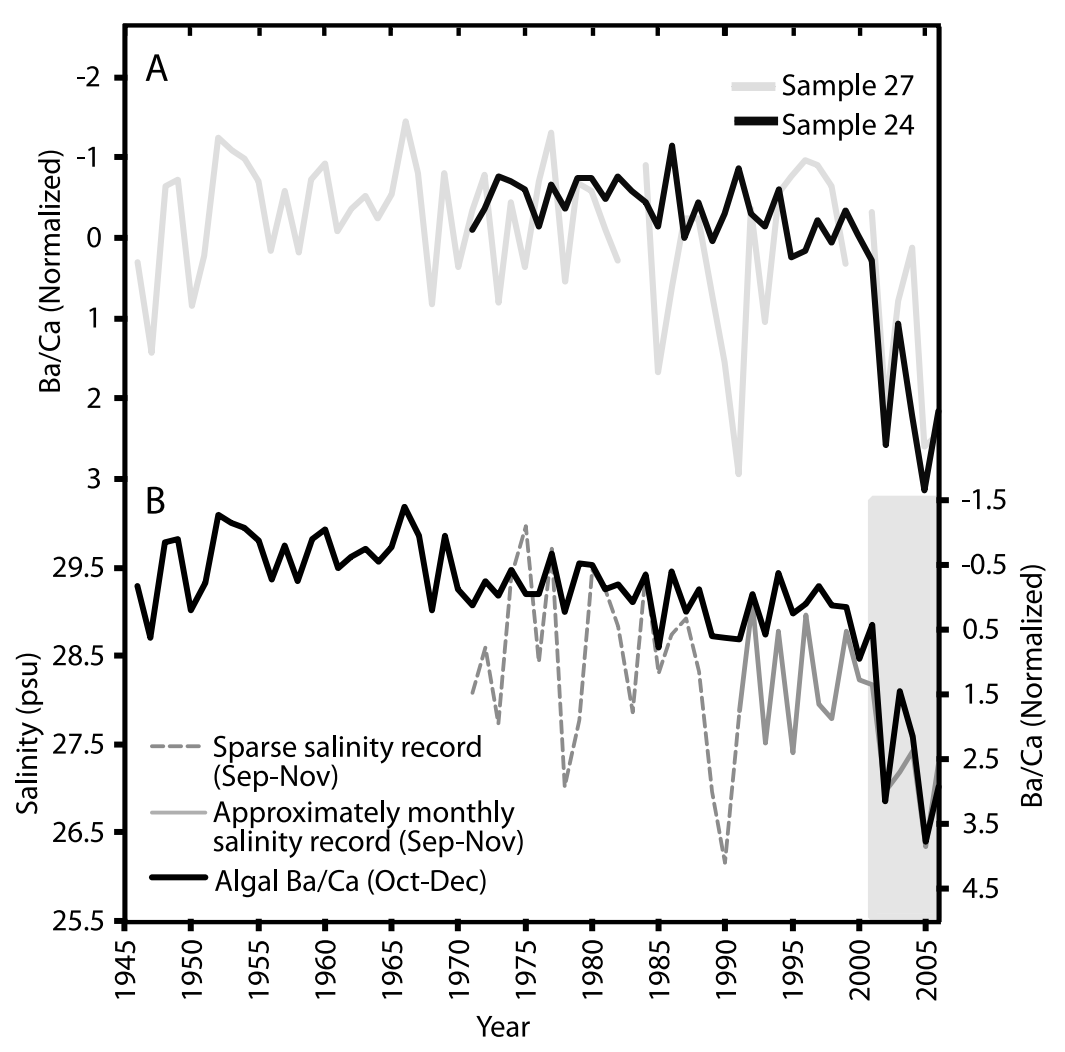

Figure 6. (a) C. nereostratum $\mathrm{Ba} / \mathrm{Ca}$ time series from samples 24 and 27 . Overlapping regions in laser transects were averaged to create the final $\mathrm{Ba} / \mathrm{Ca}$ time series (shown in Figure $6 \mathrm{~b}$ ). (b) Subannual GAK 1 (September-November) highly correlates to (October-December) algal Ba/Ca (1971-2006) $(\mathrm{n}=35, r=$ $-0.65, \mathrm{p}<0.0001$ ). The period of scarce oceanographic measurements (prior to 1991, where observations in 5 or more months of the year are missing) is indicated by dashed gray line. Period of quasi-monthly instrumental measurements (post 1991) is indicated by solid line. Grey bar highlights the significant multiyear freshening of the Alaska Coastal Current from 2001 to 2006 recorded by both instrumental and algal records.

of the Alaska Coastal Current recorded by algal $\mathrm{Ba} / \mathrm{Ca}$ ratios and GAK 1 observations was also detected in mooringbased studies of Bering Strait throughflow, which shows an incremental freshening of water masses with a combined Alaska Coastal Current and western Alaska river outflow signature along the eastern Strait from 2002 to 2004 [Woodgate et al., 2006]. In addition, a long-term decrease in salinity of about $0.06 \mathrm{psu}$ in the upper $100 \mathrm{~m}$ at GAK 1 since 1970 is consistent with increasing algal $\mathrm{Ba} / \mathrm{Ca}$ ratios and an increase in freshwater runoff off mainland Alaska over the same time period [Royer, 2005]. The observed freshening of the Alaska Coastal Current is likely due to an increase in annual mean air temperatures, generating a longer warm season and a shorter ice season [Stroeve et al., 2005; Woodgate et al., 2006], resulting in an increased rate of glacial thinning in southeast Alaska since the mid-1990s [Arendt et al., 2002, 2009]. In addition, warmer air temperatures lead to enhanced moisture transport and coastal precipitation along the Gulf of Alaska [Weingartner et al., 2005; Janout et al., 2009]. In mountainous coastal regions such as the Gulf of Alaska where there is a steep weathering terrain, high suspended sediment loads in seasonal runoff likely deliver large volumes of barium-enriched freshwater to coastal regions [Coffey et al., 1997; Guay and Falkner, 1997]. In fact, extremely high Ba concentrations were de- tected on the eastern side of the Bering Strait associated with the Alaska Coastal Current [Guay and Falkner, 1997]. Although upwelling could potentially be a significant source of barium in surface water masses, it is unlikely to occur during the fall when the coastal environment in the Gulf of Alaska is dominated by freshwater discharge and downwelling-favorable winds. The resulting freshwater cap enhances vertical stratification, thus preventing mixing of deep nutrient-rich water with the surface [Weingartner, 2007]. Both the instrumentally measured elevated barium concentrations of the Alaska Coastal Current and the subsequent depletion of barium by biological scavenging after passage of the Alaska Coastal Current into the Arctic Chukchi Sea [Guay and Falkner, 1997] likely point to a largely conservative behavior of $\mathrm{Ba}$ in the lower reaches of the Alaska Coastal Current. This, however, does not preclude that at least some of the barium signal recorded by the Unimak Pass algae is influenced by nonconservative behavior of barium. Nonconservative behavior of barium would result in the coralline algal $\mathrm{Ba} / \mathrm{Ca}$ signal to be dampened with respect to the amount of barium introduced into the Gulf of Alaska.

[13] In contrast to the Unimak Pass algal $\mathrm{Mg} / \mathrm{Ca}$ time series, multidecadal variability (e.g., Pacific Decadal Oscillation) is not evident in the 60 year $\mathrm{Ba} / \mathrm{Ca}$ record. This is similar to 
instrumental observations at GAK 1, where interannual temperature variability follows the Pacific Decadal Oscillation but salinity anomalies show no relationship to the Pacific Decadal Oscillation [Royer, 2005]. Hence, 21st century freshening of the Alaska Coastal Current as indicated by algal $\mathrm{Ba} / \mathrm{Ca}$ ratios and instrumental observations is not part of multidecadal North Pacific climate variability and is not observed in the earlier portion of the 60 yearlong algal $\mathrm{Ba} / \mathrm{Ca}$ time series. This suggests that recent freshening of the Alaska Coastal Current is unprecedented in the past 60 years.

\section{Conclusions}

[14] We use $\mathrm{Mg} / \mathrm{Ca}$ and $\mathrm{Ba} / \mathrm{Ca}$ ratios of the long-lived coralline alga Clathromorphum nereostratum collected from within the flow path of the Alaska Coastal Current to provide a 60 year record of temperature and freshwater variability. While $\mathrm{Mg} / \mathrm{Ca}$ ratios track temperature variability associated with the Pacific Decadal Oscillation, $\mathrm{Ba} / \mathrm{Ca}$ ratios exhibit no multidecadal variability, but closely relate to instrumental salinity observations for the period of overlap between the time series. Based on this relationship, algal $\mathrm{Ba} / \mathrm{Ca}$ ratios are used as a tracer of coastal freshwater runoff into the Gulf of Alaska for the past 60 years. While it remains to be tested if this relationship has been robust over longer time frames, both instrumental data and algal $\mathrm{Ba} / \mathrm{Ca}$ ratios indicate a period of enhanced freshening in the 21 st century superimposed on a long-term trend of decreasing salinities of the Alaska Coastal Current since the 1970s. Recent freshening of the Alaska Coastal Current, which plays an important role in delivering freshwater into the Bering Sea and possibly even the Arctic Ocean, is attributed to enhanced coastal freshwater and sediment discharge. Enhanced coastal discharge in turn is a likely result of warming air temperatures resulting in an increase in coastal precipitation in the Gulf of Alaska, as well as an increase in the rate of glacial thinning in southeast Alaska. Episodes similar to the 21 st century freshening are not observed in the earlier portion of the 60 yearlong algal $\mathrm{Ba} / \mathrm{Ca}$ time series, indicating that the recent Alaska Coastal Current freshening is unique in the last 60 years.

[15] Acknowledgments. This manuscript was improved by comments from the editors and two anonymous reviewers. This research was funded by Natural Sciences and Engineering Research Council of Canada Discovery and Ship Time grants to J.H. Special thanks to the captain and crew of R/V Norseman.

\section{References}

Aagaard, K., T. J. Weingartner, S. L. Danielson, R. A. Woodgate, G. C. Johnson, and T. E. Whitledge (2006), Some controls on flow and salinity in Bering Strait, Geophys. Res. Lett., 33, L19602, doi:10.1029/ 2006GL026612.

Alibert, C., L. Kinsley, S. J. Fallon, M. T. McCulloch, R. Berkelmans, and F. McAllister (2003), Source of trace element variability in Great Barrier Reef corals affected by the Burdekin flood plumes, Geochim. Cosmochim. Acta, 67(2), 231-246, doi:10.1016/S0016-7037(02) 01055-4.

Arendt, A., K. A. Echelmeyer, W. D. Harrison, C. S. Lingle, and V. B. Valentine (2002), Rapid wastage of Alaska glaciers and their contribution to rising sea level, Science, 297(5580), 382-386, doi:10.1126/science. 1072497.

Arendt, A., J. Walsh, and W. Harrison (2009), Changes of glaciers and climate in northwestern North America during the late twentieth century, J. Clim., 22(15), 4117-4134, doi:10.1175/2009JCLI2784.1.
Bishop, J. K. B. (1988), The barite-opal-organic carbon association in oceanic particulate matter, Nature, 332(6162), 341-343, doi:10.1038 $332341 \mathrm{a} 0$

Borremans, C., J. Hermans, S. Baillon, L. Andre, and P. Dubois (2009), Salinity effects on the $\mathrm{Mg} / \mathrm{Ca}$ and $\mathrm{Sr} / \mathrm{Ca}$ in starfish skeletons and the echinoderm relevance for paleoenvironmental reconstructions, Geology, 37(4), 351-354, doi:10.1130/G25411A.1.

Chan, L. H., D. Drummond, J. M. Edmond, and B. Grant (1977), On the barium data from the Atlantic GEOSECS Expedition, Deep Sea Res. 24(7), 613-649, doi:10.1016/0146-6291(77)90505-7.

Coffey, M., F. Dehairs, O. Collette, G. Luther, T. Church, and T. Jickells (1997), The behaviour of dissolved barium in estuaries, Estuarine Coastal Shelf Sci., 45(1), 113-121, doi:10.1006/ecss.1996.0157.

Collier, R., and J. Edmond (1984), The trace-element geochemistry of marine biogenic particulate matter, Prog. Oceanogr., 13(2), 113-199, doi:10.1016/0079-6611(84)90008-9.

Dehairs, F., R. Chesselet, and J. Jedwab (1980), Discrete suspended particles of barite and the barium cycle in the open ocean, Earth Planet. Sci. Lett., 49(2), 528-550, doi:10.1016/0012-821X(80)90094-1.

Dehairs, F., C. E. Lambert, R. Chesselet, and N. Risler (1987), The biological production of marine suspended barite and the barium cycle in the western Mediterranean Sea, Biogeochemistry, 4(2), 119-139, doi:10.1007/ BF02180151.

Falkner, K. K., G. P. Klinkhammer, T. S. Bowers, J. F. Todd, B. L. Lewis, W. M. Landing, and J. M. Edmond (1993), The behavior of barium in anoxic marine waters, Geochim. Cosmochim. Acta, 57(3), 537-554, doi:10.1016/0016-7037(93)90366-5.

Falkner, K. K., R. W. MacDonald, E. C. Carmack, and T. Weingartner (1994), The potential of barium as a tracer of Arctic water masses, in The Polar Oceans and Their Role in Shaping the Global Environment: The Nansen Centennial Volume, Geophys. Monogr. Ser., vol. 85, edited by O. M. Johannessen, R. D. Muench, and J. E. Overland, pp. 63-76, AGU, Washington, D. C.

Ferguson, J. E., G. M. Henderson, M. Kucera, and R. E. M. Rickaby (2008), Systematic change of foraminiferal $\mathrm{Mg} / \mathrm{Ca}$ ratios across a strong salinity gradient, Earth Planet. Sci. Lett., 265(1-2), 153-166, doi:10.1016/j.eps1.2007.10.011.

Fleitmann, D., R. B. Dunbar, M. McCulloch, M. Mudelsee, M. Vuille, T. R. McClanahan, J. E. Cole, and S. Eggins (2007), East African soil erosion recorded in a 300 year old coral colony from Kenya, Geophys. Res. Lett., 34, L04401, doi:10.1029/2006GL028525.

Gamboa, G., J. Halfar, S. Hetzinger, W. Adey, T. Zack, B. Kunz, and D. E. $\mathrm{Jacob}$ (2010), $\mathrm{Mg} / \mathrm{Ca}$ ratios in coralline algae record northwest Atlantic temperature variations and North Atlantic Oscillation relationships, J. Geophys. Res., 115, C12044, doi:10.1029/2010JC006262.

Grove, C. A., R. Nagtegaal, J. Zinke, T. Scheufen, B. Koster, S. Kasper, M. T. McCulloch, G. van den Bergh, and G. J. A. Brummer (2010), River runoff reconstructions from novel spectral luminescence scanning of massive coral skeletons, Coral Reefs, 29(3), 579-591, doi:10.1007/ s00338-010-0629-y

Guay, C. K., and K. K. Falkner (1997), Barium as a tracer of Arctic halocline and river waters, Deep Sea Res., Part II, 44(8), 1543-1569, doi:10.1016/S0967-0645(97)00066-0.

Guay, C. K., and K. K. Falkner (1998), A survey of dissolved barium in the estuaries of major Arctic rivers and adjacent seas, Cont. Shelf Res., 18(8), 859-882, doi:10.1016/S0278-4343(98)00023-5.

Halfar, J., R. Steneck, B. Schone, G. W. K. Moore, M. Joachimski, A. Kronz, J. Fietzke, and J. Estes (2007), Coralline alga reveals first marine record of subarctic North Pacific climate change, Geophys. Res. Lett., 34, L07702, doi:10.1029/2006GL028811.

Halfar, J., R. S. Steneck, M. Joachimski, A. Kronz, and A. D. Wanamaker (2008), Coralline red algae as high-resolution climate recorders, Geology, 36(6), 463-466, doi:10.1130/G24635A.1.

Hanor, J. S., and L. H. Chan (1977), Non-conservative behavior of barium during mixing of Mississippi River and Gulf of Mexico waters, Earth Planet. Sci. Lett., 37(2), 242-250, doi:10.1016/0012-821X(77)90169-8.

Hetzinger, S., J. Halfar, A. Kronz, R. S. Steneck, W. Adey, P. A. Lebednik, and B. R. Schone (2009), High-resolution $\mathrm{Mg} / \mathrm{Ca}$ ratios in a coralline red alga as a proxy for Bering Sea temperature variations from 1902 to 1967 , Palaios, 25(5-6), 406-412, doi:10.2110/palo.2008.p08-116r.

Hetzinger, S., J. Halfar, T. Zack, D. Jacob, B. Kunz, G. Gamboa, A. Kronz, W. Adey, P. Lebednik, and R. Steneck (2011), High-resolution analysis of trace elements from the North Atlantic and North Pacific in encrusting coralline algae by laser ablation ICP-MS, Palaeogeogr. Palaeoclimatol. Palaeoecol., 302, 81-94, doi:10.1016/j.palaeo.2010.06.004.

Jacob, D. E. (2006), High sensitivity analysis of trace element-poor geological reference glasses by laser ablation-inductively coupled plasma-mass spectrometry (LA-ICP-MS), Geostand. Geoanal. Res., 30(3), 221-235, doi:10.1111/j.1751-908X.2006.tb01064.x. 
Janout, M. A., T. J. Weingartner, S. R. Okkonen, T. E. Whitledge, and D. L. Musgave (2009), Some characteristics of Yakutat Eddies propagating along the continental slope of the northern Gulf of Alaska, Deep Sea Res., Part II, 56(24), 2444-2459, doi:10.1016/j.dsr2.2009.02.006.

Janout, M. A., T. J. Weingartner, T. C. Royer, and S. L. Danielson (2010), On the nature of winter cooling and the recent temperature shift on the northern Gulf of Alaska shelf, J. Geophys. Res., 115, C05023, doi:10.1029/2009JC005774

Kamenos, N. A., M. Cusack, and P. G. Moore (2008), Coralline algae are global palaeothermometers with bi-weekly resolution, Geochim. Cosmochim. Acta, 72(3), 771-779, doi:10.1016/j.gca.2007.11.019.

Kisakürek, B., A. Eisenhauer, F. Böhm, D. Garbe-Schönberg, and J. Erez (2008), Controls on shell $\mathrm{Mg} / \mathrm{Ca}$ and $\mathrm{Sr} / \mathrm{Ca}$ in cultured planktonic foraminiferan, Globigerinoides ruber (white), Earth Planet. Sci. Lett., 273(3-4), 260-269, doi:10.1016/j.eps1.2008.06.026.

Kuhlbrodt, T., S. Rahmstorf, K. Zickfeld, F. B. Vikebo, S. Sundby, M. Hofmann, P. M. Link, A. Bondeau, W. Cramer, and C. Jaeger (2009), An integrated assessment of changes in the thermohaline circulation, Clim. Change, 96(4), 489-537, doi:10.1007/s10584-009-9561-y.

Ladd, C., and P. J. Stabeno (2009), Freshwater transport from the Pacific to the Bering Sea through Amukta Pass, Geophys. Res. Lett., 36, L14608, doi:10.1029/2009GL039095.

Lea, D., and E. Boyle (1989), Barium content of benthic foraminifera controlled by bottom-water composition, Nature, 338(6218), 751-753, doi:10.1038/338751a0.

Lea, D. W., and E. A. Boyle (1991), Barium in planktonic foraminifera, Geochim. Cosmochim. Acta, 55(11), 3321-3331, doi:10.1016/00167037(91)90491-M.

Lea, D. W., G. T. Shen, and E. A. Boyle (1989), Coralline barium records temporal variability in equatorial Pacific upwelling, Nature, 340(6232), 373-376, doi:10.1038/340373a0.

Li, Y. H., and L. H. Chan (1979), Desorption of Ba and Ra-226 from riverborne sediments in the Hudson Estuary, Earth Planet. Sci. Lett., 43(3), 343-350, doi:10.1016/0012-821X(79)90089-X

Mantua, N. J., S. R. Hare, Y. Zhang, J. M. Wallace, and R. C. Francis (1997), A Pacific interdecadal climate oscillation with impacts on salmon production, Bull. Am. Meteorol. Soc., 78, 1069-1079, doi:10.1175/15200477(1997)078<1069:APICOW>2.0.CO;2.

McCulloch, M., S. Fallon, T. Wyndham, E. Hendy, J. Lough, and D. Barnes (2003), Coral record of increased sediment flux to the inner Great Barrier Reef since European settlement, Nature, 421(6924), 727-730, doi:10.1038/ nature01361.

Mizobata, K., K. Shimada, R. Woodgate, S. I. Saitoh, and J. Wang (2010), Estimation of heat flux through the eastern Bering Strait, J. Oceanogr., 66(3), 405-424, doi:10.1007/s10872-010-0035-7.

Paillard, D., L. Labeyrie, and P. Yiou (1996), Macintosh program performs time-series analysis, Eos Trans. $A G U, 77,379$, doi:10.1029/96EO00259.

Paquette, R. G., and R. H. Bourke (1981), Ocean circulation and fronts as related to ice melt-back in the Chukchi Sea, J. Geophys. Res., 86(C5), 4215-4230, doi:10.1029/JC086iC05p04215.

Peterson, B. J., R. M. Holmes, J. W. McClelland, C. J. Vorosmarty, R. B. Lammers, A. I. Shiklomanov, I. A. Shiklomanov, and S. Rahmstorf(2002), Increasing river discharge to the Arctic Ocean, Science, 298(5601), 21712173, doi:10.1126/science. 1077445 .

Rahmstorf, S. (1995), Bifurcations of the Atlantic thermohaline circulation in response to changes in the hydrologic cycle, Nature, 378(6553), 145-149, doi:10.1038/378145a0.

Reynolds, R. W., N. A. Rayner, T. M. Smith, D. C. Stokes, and W. Q. Wang (2002), An improved in situ and satellite SST analysis for climate, J. Clim., 15(13), 1609-1625, doi:10.1175/1520-0442(2002)015<1609: AIISAS $>2.0 . \mathrm{CO} ; 2$.

Royer, T. C. (1982), Coastal freshwater discharge in the northeast Pacific, J. Geophys. Res., 87(C3), 2017-2021, doi:10.1029/JC087iC03p02017.
Royer, T. C. (2005), Hydrographic responses at a coastal site in the northern Gulf of Alaska to seasonal and interannual forcing, Deep Sea Res., Part II, 52(1-2), 267-288, doi:10.1016/j.dsr2.2004.09.022.

Royer, T. C., and C. E. Grosch (2006), Ocean warming and freshening in the northern Gulf of Alaska, Geophys. Res. Lett., 33, L16605, doi:10.1029/2006GL026767.

Schumacher, J. D., C. A. Pearson, and J. E. Overland (1982), On exchange of water between the Gulf of Alaska and the Bering Sea through Unimak Pass, J. Geophys. Res., 87(C8), 5785-5795, doi:10.1029/JC087iC08p05785.

Shen, G. T., and E. A. Boyle (1988), Determination of lead, cadmium and other trace metals in annual-banded corals, Chem. Geol., 67(1-2), 47-62, doi:10.1016/0009-2541(88)90005-8.

Shimada, K., T. Kamoshida, M. Itoh, S. Nishino, E. Carmack, F. McLaughlin, S. Zimmermann, and A. Proshutinsky (2006), Pacific Ocean inflow: Influence on catastrophic reduction of sea ice cover in the Arctic Ocean, Geophys. Res. Lett., 33, L08605, doi:10.1029/2005GL025624.

Sinclair, D. J., and M. T. McCulloch (2004), Corals record low mobile barium concentrations in the Burdekin River during the 1974 flood: Evidence for limited Ba supply to rivers?, Palaeogeogr. Palaeoclimatol. Palaeoecol., 214(1-2), 155-174.

Sinclair, D. J., L. P. J. Kinsley, and M. T. McCulloch (1998), High resolution analysis of trace elements in corals by laser ablation ICP-MS, Geochim. Cosmochim. Acta, 62(11), 1889-1901, doi:10.1016/S0016-7037(98) 00112-4.

Stabeno, P. J., R. K. Reed, and J. M. Napp (2002), Transport through Unimak Pass, Alaska, Deep Sea Res., Part II, 49(26), 5919-5930, doi:10.1016/S0967-0645(02)00326-0.

Stroeve, J. C., M. C. Serreze, F. Fetterer, T. Arbetter, W. Meier, J. Maslanik, and K. Knowles (2005), Tracking the Arctic's shrinking ice cover: Another extreme September minimum in 2004, Geophys. Res. Lett., 32, L04501, doi:10.1029/2004GL021810

Weingartner, T. J. (2007), The physical environment of the Gulf of Alaska, in Long-Term Ecological Change in the Northern Gulf of Alaska, edited by R. B. Spies, pp. 12-40, Elsevier, Amsterdam.

Weingartner, T. J., S. L. Danielson, and T. C. Royer (2005), Freshwater variability and predictability in the Alaska Coastal Current, Deep Sea Res., Part II, 52(1-2), 169-191, doi:10.1016/j.dsr2.2004.09.030.

Woodgate, R. A., and K. Aagaard (2005), Revising the Bering Strait freshwater flux into the Arctic Ocean, Geophys. Res. Lett., 32, L02602, doi:10.1029/2004GL021747.

Woodgate, R. A., K. Aagaard, J. H. Swift, K. K. Falkner, and W. M. Smethie Jr. (2005), Pacific ventilation of the Arctic Ocean's lower halocline by upwelling and diapycnal mixing over the continental margin, Geophys. Res. Lett., 32, L18609, doi:10.1029/2005GL023999.

Woodgate, R. A., K. Aagaard, and T. J. Weingartner (2006), Interannual changes in the Bering Strait fluxes of volume, heat and freshwater between 1991 and 2004, Geophys. Res. Lett., 33, L15609, doi:10.1029/ 2006GL026931.

Woodgate, R. A., T. Weingartner, and R. Lindsay (2010), The 2007 Bering Strait oceanic heat flux and anomalous Arctic sea-ice retreat, Geophys. Res. Lett., 37, L01602, doi:10.1029/2009GL041621.

P. Chan, J. Halfar, and B. Williams, Chemical and Physical Sciences Department, University of Toronto, 3359 Mississauga Rd. N., Mississauga, ON L5L 1C6, Canada. (phoebetw.chan@utoronto.ca)

S. Hetzinger, Leibniz Institute of Marine Sciences at University of Kiel (IFM-GEOMAR), Wischhofstr. 1-3, D-24148 Kiel, Germany.

D. E. Jacob and T. Zack, Earth System Science Research Centre, Johannes Gutenberg-Universität, Becherweg 21, D-55128 Mainz, Germany. R. Steneck, Darling Marine Center, University of Maine, 193 Clarks Cove Rd., Walpole, ME 04573, USA. 